Article

\title{
Regioselective Palmitoylation of 9-(2,3- Dihydroxy- propyl)adenine Catalyzed by a Glycopolymer-enzyme Conjugate
}

\author{
Jana Brabcová $^{1}$, Jiří Blažek ${ }^{1}$, Marcela Krečmerová ${ }^{1}$, Jiří Vondrášek ${ }^{1}$, Jose M. Palomo ${ }^{2, *}$ and \\ Marie Zarevúcka ${ }^{1, *}$ \\ 1 Institute of Organic Chemistry and Biochemistry, AS CR, Flemingovo nám. 2, Prague 6, Czech Republic; \\ brabcova@uochb.cas.cz (J.B.); blazek@uochb.cas.cz (J.B.); krecmerova@uochb.cas.cz (M.K.); \\ vondrasek@uochb.cas.cz (J.V.) \\ 2 Departamento de Biocatálisis, Instituto de Catálisis (CSIC) Campus UAM Cantoblanco, Madrid 28049, Spain \\ * Correspondence: josempalomo@icp.csic.es (J.M.P.); zarevucka@uochb.cas.cz (M.Z.); \\ Tel.: +34-91-585-4800 (J.M.P.); +420-220-183-281 (M.Z.)
}

Academic Editor: Derek J. McPhee

Received: 28 March 2016; Accepted: 10 May 2016; Published: 16 May 2016

\begin{abstract}
The enzymatic regioselective monopalmitoylation of racemic 9-(2,3-dihydroxypropyl)adenine (DHPA), an approved antiviral agent, has been performed by an immobilized form of Candida antarctica B lipase (CAL-B) using a 4:1 DMF/hexane mixture as the reaction medium. To improve the chemical yield of the desired monopalmitoylation reaction, solid-phase chemical modifications of the lipase were evaluated. The reaction yield was successfully increased obtaining $100 \%$ product after a second treatment of the product solution with fresh immobilised chemically glycosylated-CAL-B.
\end{abstract}

Keywords: regioselectivity; palmitoylation; glycosylation; chemical modification

\section{Introduction}

Acyclic nucleoside analogues are a class of molecules demonstrating antiviral activity [1-5]. Several representatives of this group such as acyclovir, ganciclovir or penciclovir (Figure 1) are approved antiviral agents with activity targeted against herpes viruses. A promising candidate is 9-(2,3-dihydroxypropyl)adenine (DHPA), which has shown antiviral potency by the inhibition of $S$-adenosylhomocysteine (SAH) hydrolase [6,7]. Indeed, this molecule is an approved drug for the topical treatment of herpes labialis (HSV-1) in the former Czechoslovakia, marketed under the name Duvira ${ }^{\circledR}$ gel. However, the low oral bioavailability of all acyclic nucleoside analogues is a limitation for their use as topical drugs only.<smiles>NC1=NC(=O)C2N=CN(COCO)C2=N1</smiles>

Acyclovir<smiles>NC1=NC(=O)C2N=CN(COC(CO)CO)C2=N1</smiles>

Ganciclovir<smiles>NC1=NC(=O)C2N=CN(CCC(CO)CO)C2=N1</smiles>

Penciclovir

Figure 1. Acyclic nucleoside antiviral agents.

The modification of the drugs by hydrophobic moieties has been established as a successful strategy for improving their bioavailability and pharmacological properties [8-12]. Among the different 
hydrophobic groups available, the introduction of a palmitoyl moiety might be an advantage, because it is one of the lipids constituting the plasmatic membrane. Palmitic acid has been shown as a typical group for example for the membrane binding and membrane targeting of lipidated proteins $[13,14]$. In this way, the introduction of only one hydrophobic moiety by a specific and regioselective way would be mandatory to improve drug bioavailability. For that purpose, the application of a green biocatalytic approach seems to be an excellent alternative.

Lipases are popular enzymes utilized for esterification reactions in organic synthesis [15-17]. Although they are highly versatile, specificity or regioselectivity are sometimes not expected. Therefore, the application of immobilization techniques [18-20] or chemical modification approaches [21-26] has chemically modified lipases, especially after the protein glycosylation process on the solid phase made it possible to overcome these drawbacks, obtaining exceptional improvements of catalytic properties, giving excellent enantio- or regioselective catalysts for example in carbohydrate or nucleoside deprotection $[27,28]$, the acylation of cholesterol analogues [29] or the desymmetrisation of prochiral molecules [30].

Here we present the enzymatic palmitoylation of DHPA catalysed by immobilised lipases. Moreover, the cytotoxicity and antiviral activity of the $S$-enantiomer of palmitoylated DHPA in different cell cultures were evaluated.

\section{Results and Discussion}

First, a screening of different lipases (Candida antarctica, Pseudomonas fluorescens, Bacillus thermocatenulatus and Thermomyces lanuginosus) soluble and in immobilized form (Lewatit 1600, octadecyl-Sepabeads or Purolite) for a suitable candidate for the enzymatic palmitoylation of DHPA (Scheme 1) was evaluated. Candida antarctica lipase B immobilized on Lewatit 1600 resin (Lew-CAL-B) was the only biocatalyst active in the esterification in neat DMF, although low conversion was noticed (entry 1, Table 1), demonstrating the difficulty of this enzymatic process.

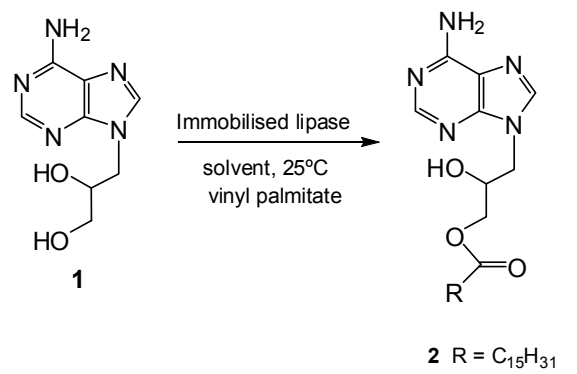

Scheme 1. Enzymatic esterification of DHPA.

Table 1. The effect of solvent in the palmitoylation of DHPA catalysed by Lew-CAL-B.

\begin{tabular}{ccc}
\hline Entry & Solvent & Conversion 2 (\%) \\
\hline 1 & DMF & 2 \\
2 & DMF: Hexane $(4: 1)$ & 6.4 \\
3 & DMF: Hexane (3:2) & 5.9 \\
4 & DMF: Ionic liquid ${ }^{\mathrm{b}}(4: 1)$ & 0.6 \\
5 & DMF: 2-methyl-2-butanol (4:1) & 6.2 \\
6 & DMF:Pyridine (4:1) & 1.1 \\
\hline
\end{tabular}

a conversion after $24 \mathrm{~h}$ measured by HPLC. The reaction conditions were: $1.6 \mathrm{mM}$ DHPA, vinyl palmitate (1:10) and $50 \mathrm{mg}$ of Lewatit-CAL-B (130 U/g); ${ }^{\text {b }}$ 1-butyl-3-methylimidazolium tetrafluoroborate.

Thus, the biotransformation was performed using different DMF-solvent combinations, considering our experience with the solubility of the DHPA in water and specially the ester derivative [31]. 
To address this issue, the addition of hexane improved the palmitoylation yield, with $6.4 \%$ after $24 \mathrm{~h}$ using 20\% $(v / v)$ hexane in the final volume mixture (entry 2, Table 1). The addition of 2-methyl-2-butanol in the same proportion also gave positive results but the presence of pyridine or ionic liquids in the solvent mixture produced a negative result for the esterification capacity of the biocatalyst (Table 1).

Thus different chemical modification strategies (by non-covalent or covalent attachment of molecules to the protein) were then applied to the Lew-CAL-B preparation (Figure 2). One strategy was based on the coating of the protein surface of the immobilized enzyme by using polyethylenimine (PEI) (Lew-CAL-B-PEI). Another strategy was the modification of the carboxylic groups of residues in Asp and Glu amino acids in the protein by covalent modification using carbodiimide as the activating agent (Lew-CAL-B-EDA). Finally two specific strategies were then applied to modify the $N$-terminus of the protein. A monocarboxylated polyethylene (mcPEG1500) and a glycosylated dextran polymer (D1500) were used obtaining the respective heterogeneous semisynthetic enzymes (Lew-CAL-B-mc-PEG and Lew-CAL-B-D1500).

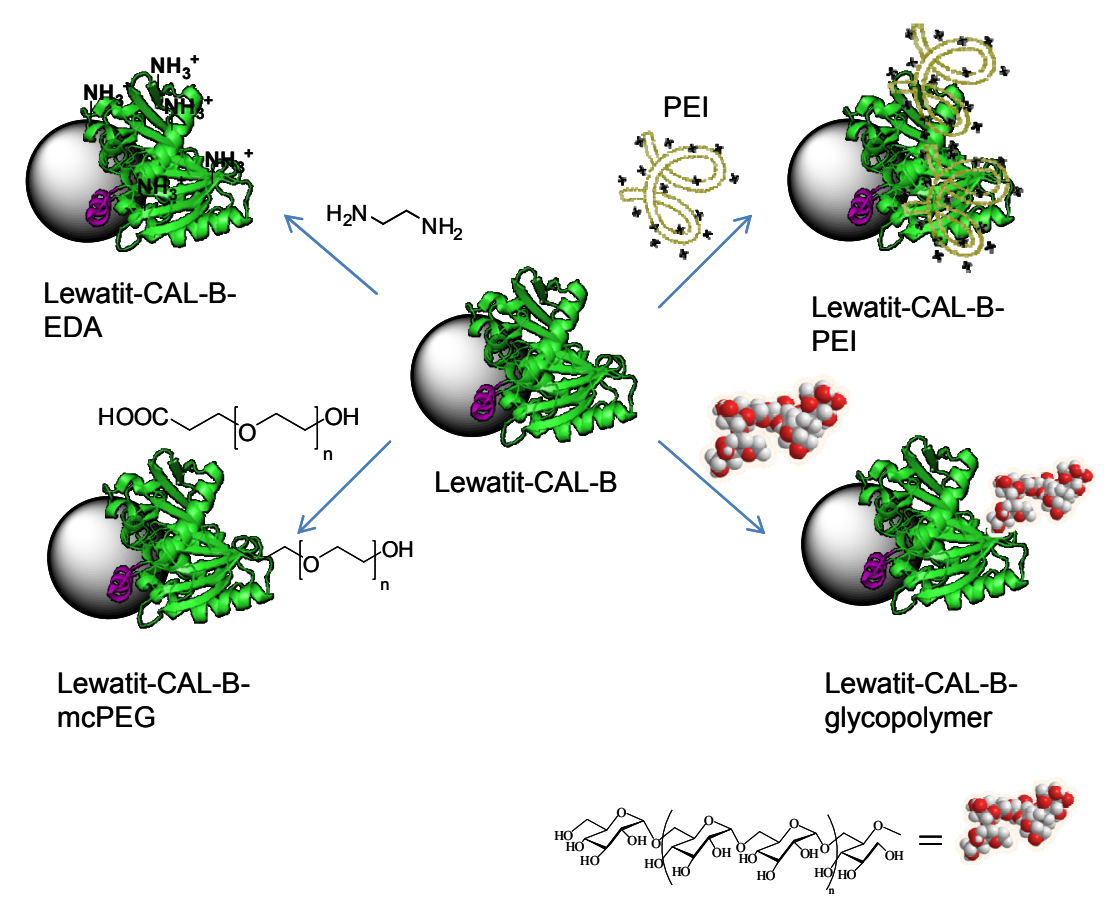

Figure 2. Different chemical modification of Lewatit-CAL-B on the solid phase.

These new catalysts were used in the monopalmitoylation of $\mathbf{1}$ under the optimal conditions after $24 \mathrm{~h}$ (Table 2). The Lew-CAL-B-EDA preparation exhibited 50\% less active when compared with the non-modified biocatalyst. This denotes the possibility of the coating with PEI and the chemical modification with the PEG (Lew-CAL-B-PEI and Lew-CAL-B-mc-PEG preparations) improved the enzyme activity by three-fold and still produced the palmitoylated $\mathbf{2}$ in moderate yield.

However, the site-specific glycosylation of the N-terminus of CAL-B by the glypolymer D1500 enhanced the synthetic activity towards the production of 2 with almost $50 \%$ yield (almost 10 times higher when compared to the non-modified one). Moreover a full conversion (>99\%) of 2 was obtained after the second treatment of the product solution with the heterogeneous semisynthetic enzyme (Lew-CAL-B-D1500). Also the site-selective glycosylation was carried out or proceeded by using other activated bigger-size polymers however no improvements were found. 
Table 2. Synthesis of monopalmitoylated DHPA catalysed by different chemically modified derivatives of the Lew-CAL-B ${ }^{a}$.

\begin{tabular}{ccc}
\hline Entry & Modified Biocatalysts & Conversion 2 (\%) \\
\hline 1 & - & 6.2 \\
2 & Lew-CAL-B-EDA & 3.5 \\
3 & Lew-CAL-B-PEI & 16.2 \\
4 & Lew-CAL-B-mc-PEG & 19.4 \\
5 & Lew-CAL-B-D1500 & $49.9(>99)^{\mathrm{b}}$ \\
\hline
\end{tabular}

a conversion after $24 \mathrm{~h}$. The reactions conditions were: $1.6 \mathrm{mM}$ DHPA, vinyl palmitate (1:10) in DMF:hexane (4:1) and $50 \mathrm{mg}$ of biocatalyst; ${ }^{\mathrm{b}}>99 \%$ conversion of palmitoylation was found after second treatment with the biocatalyst.

The reaction course (Figure 3) has demonstrated that the conversion stopped after $2 \mathrm{~h}$ for Lewatit-CAL-B, whereas the specific chemical glycosylation allowed the conversion to continue from $18 \%$ at $2 \mathrm{~h}$ to $50 \%$ at $24 \mathrm{~h}$, after which (at $48 \mathrm{~h}$ ) the reaction was not significantly changed. Therefore, the glycosylation of the enzyme helped to reduce the substrate inhibition and increased the conversion progress successfully.

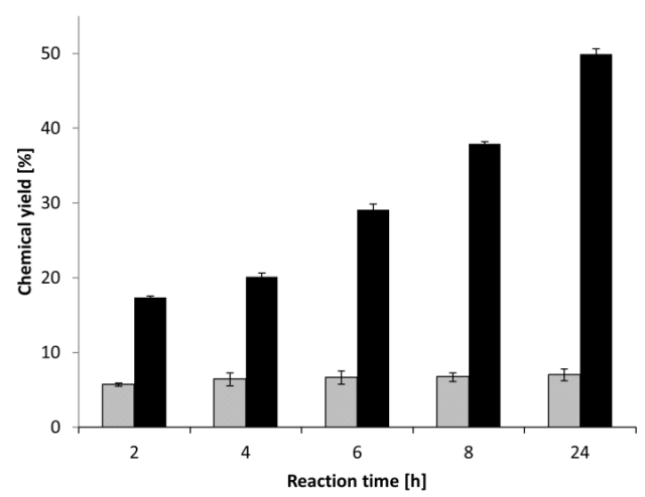

Figure 3. The reaction course of DHPA palmitoylation catalysed by Lewatit-CAL-B catalyst. Lewatit-CAL-B (gray), glycosylated Lewatit-CAL-B (black).

Furthermore the incorporation of the glycopolymer in the $N$-terminal position of the enzyme caused modifications in its secondary structure as confirmed by circular dichroism; particularly, the content of alpha-helix was reduced (Figure 4). These structural variations might explain the increase of conversion progress, which is caused by the better favouring of the substrates into the active site of CAL-B.

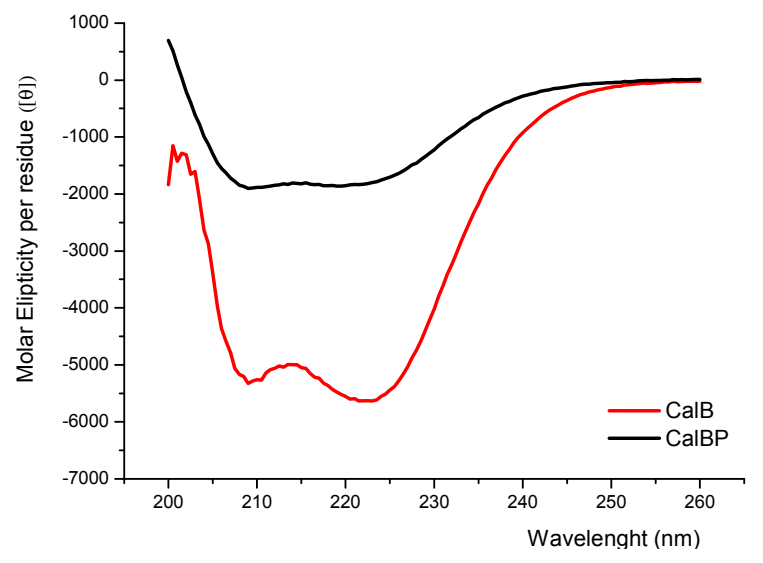

Figure 4. Circular dichroism spectra of CAL-B enzymes. CAL-B (red), glycopolymer-CAL-B (black). 
The binding mode of product 2 in the active site of the 1LBS was analyzed based on the result of the docking procedure performed by the LigX module. The final position of the ligand within the cavity provides the anatomy of the binding pocket and the amino acids participating in the interactions (Figure 5). Most of the non-covalent interactions are realized through a dispersion interaction of the aliphatic part of the ligand, with the amino acids Ser105, Gln157 and Asp134 participating in the binding (Figure 5).
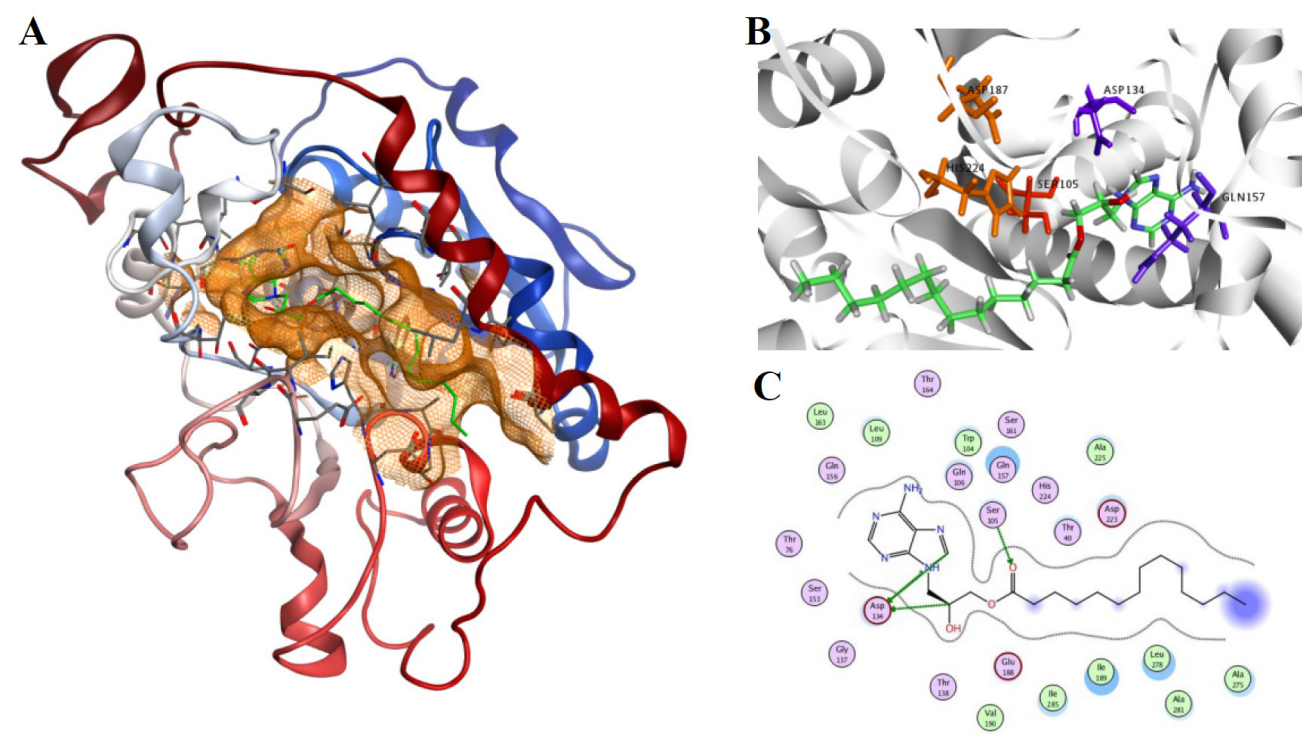

Figure 5. (A) The best model of the product 3-(6-amino-9H-purin-9-yl)-2-hydroxypropyl palmitate (2) in the active site of CAL-B. This most productive conformation situates the adenine in the large hydrophobic pocket due to a better enzyme-substrate interaction; (B) a detail of $\mathbf{2}$ (represented as green sticks) placement in the binding cavity of the lipase, the catalytic triad Asp-His-Ser is shown as orange sticks (Ser105 is red); (C) a schematic view of potential hydrogen-bond stabilisation appearing between: (i) Ser105 and the palmitoyl group; (ii) Asp134 and the $9^{\prime} \mathrm{H}$-purin of the adenine ring and 2-OH of propyl. The hydrogen bonds between ligand atoms and amino acids of the active site are shown as dotted lines. Crystal structures with pdb code 1LBS and 1LPP were used.

The S-enantiomer of DHPA has been demonstrated to exhibit interesting antiviral activity [7]. In order to obtain a compound with better bioavailability, we synthesised the palmitoylated (S)-DHPA following a previously described procedure and its biological activity was evaluated with several viruses-Para-influenza-3 virus, Reovirus-1, Sindbis virus, Coxsackie virus B4, Punta Toro virus, Vesicular stomatitis virus and Respiratory syncytial virus (data not shown). Although the concentration exhibiting biological activity was low as compared to commercial antivirals tested, the addition of the palmitoyl group increased the antiviral activity. There was a small but consistent difference from the parent analogue. The antiviral activity of $2(>100 \mu \mathrm{g} / \mathrm{mL})$ was 2.5 times higher than those of the parent compound $(>250 \mu \mathrm{g} / \mathrm{mL}$ ) for all seven types of viruses studied. This led to a hypothesis that the parent compound DHPA (1) must either be more efficiently released from its palmitoylated DHPA (2) prodrug molecule or better transported to the cells, or both. The in vivo bioavailability will be the subject for further study.

\section{Materials and Methods}

\subsection{Materials}

Dextran (Mr 1500 Da), polyethyleneglycol (PEG) (Mr 1500 Da), polyethylenimine (Mr 1200), ethylenediamine, $p$-nitrophenyl butyrate ( $p$ NPB), 1-ethyl-3-(3-dimethylaminopropyl)-carbodiimide (EDC), ethylenediamine (EDA) were from Sigma Aldrich (Prague, Czech Republic). Candida antarctica 
B lipase (CAL-B) was kindly donated by Novozymes (Bagsvaerd, Denmark). Octadecyl-Sepabeads was kindly donated by Resindion Srl. (Tokio, Japan). Lewatit1600 was from Lanxess (Cologne, Germany) and Purolite A503 was from Purolite (Barcelona, Spain). Aldehyde-activated dextran (glycopolymer D1500) and monocarboxylated PEG1500 were prepared as previously described [22]. (S)-9-(2,3-dihydroxypropyl)adenine (DHPA) was prepared as previously described [31]. All organic solvents and other reagents were of analytical grade.

\subsection{Enzyme Activity Assay}

In order to study the immobilisation process, the activities of the soluble and immobilised lipase catalysts were analysed spectrophotometrically measuring the increment in absorbance at $348 \mathrm{~nm}$ produced by the release of $p$-nitrophenol $(p N P)\left(\epsilon=50 \mathrm{M}^{-1} \cdot \mathrm{cm}^{-1}\right)$ in the hydrolysis of $0.4 \mathrm{mM}$ of $p \mathrm{NPB}$ in $25 \mathrm{mM}$ of sodium phosphate at $\mathrm{pH} 7$ and $25^{\circ} \mathrm{C}$. To initiate the reaction, $0.05-0.2 \mathrm{~mL}$ of lipase solution or suspension were added to $2.5 \mathrm{~mL}$ of substrate solution. Enzymatic activity is given as a micromole of hydrolysed $p$ NPB per minute per milligram of enzyme (IU) under the conditions described above.

\subsection{Lipase Immobilisation}

Commercial extract of CAL-B (4 mL, $4.5 \mathrm{mg}$ protein/mL measured by Bradford) was dissolved in $10 \mathrm{mM}$ sodium phosphate buffer at $\mathrm{pH} 7(16 \mathrm{~mL})$. One gram of octadecyl-Sepabeads, Lewatit 1600 or Purolite was added to this solution and the mixture was incubated at $28^{\circ} \mathrm{C}$ for $3 \mathrm{~h}$. The activity of the suspension and supernatant was assayed by the $p$ NPB assay described below. The suspension was washed with distilled water $(10$ times with $100 \mathrm{~mL})$. In all cases the immobilisation yield obtained was more than $95 \%$. Finally, the immobilised lipases were dried by incubation in an oven at $37^{\circ} \mathrm{C}$ for $2 \mathrm{~h}$ before their use in the transesterification of DHPA.

\subsection{Chemical Modification of Immobilised Lewatit-CAL-B Preparation}

A site-specific modification with glycopolymer: $10 \mathrm{~mL}$ of $10 \%$ oxidised (aldehyde) dextran representing Mw of 1500 (glycopolymer D1500) (33 mg. mL ${ }^{-1}$ ) in $100 \mathrm{mM}$ of a sodium phosphate buffer ( $\mathrm{pH}$ 7.5) were added to one gram of immobilised Lewatit-CAL-B preparation. After $36 \mathrm{~h}$ of gentle stirring, sodium borohydride $(1 \mathrm{mg} / \mathrm{mL})$ was added, followed by another addition of sodium borohydride after $15 \mathrm{~min}$. Thirty min later, the mixture was filtered and washed abundantly with water.

A site-specific modification with monocarboxylated polyethylene glycol: 1-Ethyl-3-(3-dimethy laminopropyl)carbodiimide (EDC, $50 \mathrm{mmol}$ ) and $8.2 \mu \mathrm{mol}$ of dimethylamine pyridine were added to a solution of monocarboxylated polyethylene glycol $(m c-P E G) \mathrm{Mw}=1500\left(33 \mathrm{mg} \cdot \mathrm{mL}^{-1}\right)$ in $5 \mathrm{mM}$ of a sodium phosphate buffer ( $\mathrm{pH}$ 7). One gram of biocatalyst was added to $20 \mathrm{~mL}$ of this solution, and the reaction was maintained for $48 \mathrm{~h}$. Then, the preparation was filtrated and washed abundantly with distilled water.

Chemical amination: One gram of biocatalyst was added to $10 \mathrm{~mL}$ of a solution of $1 \mathrm{M}$ of EDA. Then, solid EDC (10 mM) was added and the $\mathrm{pH}$ was adjusted to 4.75 . The preparation was incubated for $2 \mathrm{~h}$ and then washed twice with distilled water and once with $5 \mathrm{mM}$ of phosphate buffer (pH 7).

Coating with polyethyleneimine: one gram of polyethyleneimine (PEI) was dissolved at $100 \mathrm{~mL}$ solution of water/dioxane $(7 / 3, v / v)$ at $\mathrm{pH} 5$. One gram of immobilised biocatalyst was added to this solution and then solid EDC $(10 \mathrm{mM})$ was added.

The suspension was gently stirred for $1 \mathrm{~h}$ and the modified enzyme preparations were abundantly washed with distilled water.

\subsection{Transesterification Reactions}

Palmitoylation: $50 \mathrm{mg}$ of immobilised enzyme were added to $375 \mu \mathrm{L}$ of a solution consisting of DHPA (1.6 mM) and different ratios of solvent:cosolvent and vinyl palmitate (from 1 to $10 \mathrm{eq}$ ). The catalyst was dried at $40^{\circ} \mathrm{C}$ overnight and washed before reaction by DMF/hexane $(4 / 1, v / v)$. 
Molecular sieves were added into each reaction mixture (40 mg per $375 \mu \mathrm{L}$ reaction mixture). The reaction was performed in Eppendorf tubes under constant stirring at $25^{\circ} \mathrm{C}$ and the progress of the reaction was monitored by TLC analysis. The final stage consisted of the filtration off of the enzyme and the evaporation of the solvent. The reaction mixture was dissolved in the mixture chloroform:methanol (4:1) and measured by HPLC.

\subsection{Analytical Methods}

The ${ }^{1} \mathrm{H}-\mathrm{NMR}$ spectra were recorded on a UNITY 500 spectrometer (in a FT mode, Varian) at the respective 499.8 and $125.7 \mathrm{MHz}$ frequency values either in deuteriochloroform using tetramethylsilane $(\delta=0)$ as an internal reference or in hexadeuteroacetone using the central line of the solvent $(\delta=2.13)$ as an internal reference. TLC was carried out on precoated silica gel TLC plates. A column $(250 \mathrm{~mm} \times 4 \mathrm{~mm})$ filled with a Separon SGX $\mathrm{C}_{18}$ solid phase $(5 \mu \mathrm{m}$; Watrex, Prague, Czech Republic) was employed for the HPLC analysis of the sample composition using the following gradient of Solvent A (water) and Solvent B (acetonitrile): from 100\% to $0 \%$ of Solvent A in 30 min as a mobile phase at $1 \mathrm{~mL} \cdot \mathrm{min}^{-1}$. During the HPLC analysis, the compounds were detected at $254 \mathrm{~nm}$.

\section{Preparative TLC}

The products of the enzymatic reactions (the remaining DHPA, 2) were separated by preparative TLC (using $\mathrm{CHCl}_{3}: \mathrm{CH}_{3} \mathrm{OH}(4: 1)$ ) and characterised by ${ }^{1} \mathrm{H}-\mathrm{NMR}$ and ${ }^{13} \mathrm{C}-\mathrm{NMR}$ analysis.

\subsection{3-(6-Amino-9H-purin-9-yl)-2-hydroxypropyl palmitate (2)}

${ }^{1} \mathrm{H}-\mathrm{NMR}\left(\mathrm{DMSO}-\mathrm{d}_{6}\right): 8.11(1 \mathrm{H}, \mathrm{s}, \mathrm{H}-2), 8.04(1 \mathrm{H}, \mathrm{s}, \mathrm{H}-8), 7.19\left(2 \mathrm{H}, \mathrm{bs},-\mathrm{NH}_{2}\right), 5.48(1 \mathrm{H}, \mathrm{d}$, $\left.J_{\mathrm{OH}-2^{\prime}}=5.0 \mathrm{~Hz},-\mathrm{OH}\right), 4.23\left(1 \mathrm{H}, \mathrm{m}, \mathrm{H}-1^{\prime} \mathrm{b}\right), 4.06-4.14\left(2 \mathrm{H}, \mathrm{m}, \mathrm{H}-1^{\prime} \mathrm{a}, \mathrm{H}-2^{\prime}\right), 3.96\left(1 \mathrm{H}, \mathrm{bdd}, J_{\mathrm{gem}}=11.4\right.$, $\left.J_{3^{\prime} \mathrm{b}-2^{\prime}}=4.8, \mathrm{H}-3^{\prime} \mathrm{b}\right), 3.93\left(1 \mathrm{H}, \mathrm{bdd}, J_{\text {gem }}=11.4 \mathrm{~Hz}, J_{3^{\prime} \mathrm{a}-2^{\prime}}=5.3, \mathrm{H}-3^{\prime} \mathrm{a}\right), 2.27\left(2 \mathrm{H}, \mathrm{t}, J_{5^{\prime}-6^{\prime}}=7.4 \mathrm{~Hz}, \mathrm{H}-5^{\prime}\right)$, $1.50\left(2 \mathrm{H}\right.$, pent, $\left.J_{6^{\prime}-5^{\prime}}=7.3 \mathrm{~Hz}, \mathrm{H}-6^{\prime}\right), 1.17-1.31\left(12 \mathrm{H}, \mathrm{m}, \mathrm{H}-7^{\prime}-12^{\prime}\right), 0.84\left(3 \mathrm{H}, \mathrm{t}, J_{19^{\prime}-18^{\prime}}=7.0 \mathrm{~Hz}, \mathrm{H}-13^{\prime}\right)$. ${ }^{13}$ C-NMR (DMSO-d $): 173.0\left(\mathrm{C}-4^{\prime}\right), 156.1$ (C-6), 152.5 (C-2), 149.9 (C-4), 141.7 (C-8), 118.8 (C-5), 66.7 $\left(\mathrm{C}-2^{\prime}\right), 65.7\left(\mathrm{C}-3^{\prime}\right), 46.3\left(\mathrm{C}-1^{\prime}\right), 33.6\left(\mathrm{C}-5^{\prime}\right), 31.5\left(\mathrm{C}-11^{\prime}\right), 28.7-29.1\left(\mathrm{C}-7^{\prime}-10^{\prime}\right), 24.6\left(\mathrm{C}-6^{\prime}\right), 22.3\left(\mathrm{C}-12^{\prime}\right), 14.2$ $\left(\mathrm{C}-13^{\prime}\right)$. MS (ESI): $[\mathrm{M}+\mathrm{H}]^{+}=447.32$, found 448.60 .

\subsection{Circular Dichroism and Fluorescence Spectroscopy}

Circular dichroism (CD) spectra of the CAL-B and glycopolymer-CAL-B conjugate were recorded in a Chirascan spectropolarimeter (Applied Photophysics, Leatherhead, Surrey, UK) at $25( \pm 1){ }^{\circ} \mathrm{C}$. Near-UV spectra were recorded at wavelengths between 250 and $310 \mathrm{~nm}$ in a $1 \mathrm{~cm}$ path-length cuvette, with $10 \mu \mathrm{M}$ protein solutions in phosphate buffered saline, pH 7.2 (PBS; bioMerieux, Prague, Czech Republic). The far-UV spectra were measured at wavelengths between 190 and $250 \mathrm{~nm}$ in a $1 \mathrm{~mm}$ path-length cuvette, with $2 \mu \mathrm{M}$ protein solutions in the same buffer. Blank measurements were made with the appropriate buffer. Fluorescence measurements were performed in a Varian Cary Eclipse Fluorescence Spectrophotometer (Agilent Technologies, Santa Clara, CA, USA) monitoring the intrinsic tryptophan fluorescence in the different proteins, using an excitation wavelength of $280 \mathrm{~nm}$, with excitation and emission bandwidths of $5 \mathrm{~nm}$, and recording fluorescence emission spectra between 300 and $400 \mathrm{~nm}$. All spectroscopic measurements were made in water.

\subsection{Docking Experiments}

A 3D model of lipase with a ligand complex was constructed based on an X-ray structure of lipase B from Candida antarctica (1LBS PDBid). For docking and orientation of the ligand in the binding cavity, we utilised the similarity with an aliphatic ligand bound to Candida rugosa lipase (1LPP PDBid). The ligand conformation was refined by applying the LigX module of the MOE for the optimisation procedure and its final binding mode was selected by the best-fit model based on the London dG 
scoring function and the generalised Born method. Molecular images were generated with UCSF Chimera (http://www.cgl.ucsf.edu/chimera/).

\section{Conclusions}

In summary, a successful regioselective monopalmitoylation of 9-(2,3-dihydroxypropyl)- adenine has been described by using an immobilized form of a chemical glycosylated CAL-B lipase. The final product exhibited better antiviral activity than DHPA representing interesting target for future studies.

Acknowledgments: The authors thank the Ramon Areces Foundation for financial support and the Academy of Sciences of the Czech Republic (project No. M200551203). The authors are grateful to the team of Jan Balzarini at the Rega Institute for Medical Research KU Leuven (Belgium) for the screening of biological activity and thank Abian from the Institute for Biocomputation and Physics (BIFI) for technical support in the CD and fluorescent spectra as well as Ramiro Martinez from Novozymes for the generous gift of lipases. We thank Lydia Burke (Technical Dublin University, Irland) for the proof-reading of the article.

Author Contributions: Jana Brabcová and Jiř́ Vondrášek performed the experiments; Jiří Blažek, Jose M. Palomo and Marie Zarevúcka analyzed data; Jose M. Palomo and Marie Zarevúcka wrote the manuscript; Jose M. Palomo, Marie Zarevúcka and Marcela Krečmerová designed the study and experiments.

Conflicts of Interest: The authors declare no conflict of interest.

\section{References}

1. Kasthuri, M.; El Amri, C.; Lefort, V.; Perigaud, C.; Peyrottes, S. Synthesis and study of $(R)$ and (S)- $\beta$-hydroxyphosphonate acyclonucleosides as structural analogues of (S)-HPMPC (cidofovir). New J. Chem. 2014, 38, 4736-4742. [CrossRef]

2. Głowacka, I.E.; Balzarini, J.; Andrei, G.; Snoeck, R.; Schols, D.; Piotrowska, D.G. Design, synthesis, antiviral and cytostatic activity of $\omega$-(1H-1,2,3-triazol-1-yl)(polyhydroxy)alkylphosphonates as acyclic nucleotide analogues. Bioorg. Med. Chem. 2014, 22, 3629-3641. [CrossRef] [PubMed]

3. Kaiser, M.M.; Jansa, P.; Dračínský, M.; Janeba, Z. A novel type of acyclic nucleoside phosphonates derived from 2-(phosphonomethoxy)propanoic acid. Tetrahedron 2012, 68, 4003-4012. [CrossRef]

4. Xie, M.-S.; Niu, H.-Y.; Qu, G.-R.; Guo, H.-M. The development for the synthesis of chiral acyclic nucleosides and their phosphonates Review. Tetrahedron Lett. 2014, 55, 7156-7166. [CrossRef]

5. Pohl, R.; Postova Slavetinska, L.; Eng, W.S.; Keough, D.T.; Guddat, L.W.; Rejman, D. Synthesis, conformational studies, and biological properties of phosphonomethoxyethyl derivatives of nucleobases with a locked conformation via a pyrrolidine ring. Org. Biomol. Chem. 2015, 13, 4693-4705. [CrossRef] [PubMed]

6. Krečmerová, M.; George, D.; Magel, S. Herpesviridae—A Look into This Unique Family of Viruses; InTech: Rijeka, Croatia, 2012; pp. 245-270.

7. De Clercq, E.; Descamps, J.; De Somer, P.; Holý, A. (S)-9-(2,3-Dihydroxypropyl)adenine: An Aliphatic Nucleoside Analog with Broad-Spectrum Antiviral Activity. Science 1978, 200, 563-565. [CrossRef] [PubMed]

8. Xie, T.; Lim, S.M.; Westover, K.D.; Dodge, M.E.; Ercan, D.; Ficarro, S.B.; Udayakumar, D.; Gurbani, D.; Tae, H.S.; Riddle, S.M.; et al. Pharmacological targeting of the pseudokinase Her3. Nat. Chem. Biol. 2014, 10, 1006-1012. [CrossRef] [PubMed]

9. Krečmerová, M.; Pohl, R.; Masojídková, M.; Balzarini, J.; Snoeck, R.; Andrei, G. N4-Acyl derivatives as lipophilic prodrugs of cidofovir and its 5-azacytosine analogue,(S)-HPMP-5-azaC: Chemistry and antiviral activity. Bioorg. Med. Chem. 2014, 22, 2896-2906. [CrossRef] [PubMed]

10. Gao, W.-L.; Li, N.; Zong, M.-H. Enzymatic regioselective acylation of nucleosides in biomass-derived 2-methyltetrahydrofuran: Kinetic study and enzyme substrate recognition. J. Biotechnol. 2013, 164, 91-96. [CrossRef] [PubMed]

11. Ravalico, F.; James, S.L.; Vyle, J.S. Synthesis of nucleoside analogues in a ball mill: Fast, chemoselective and high yielding acylation without undesirable solvents. Green Chem. 2011, 13, 1778-1783. [CrossRef]

12. Li, N.; Zong, M.-H.; Ma, D. Regioselective acylation of nucleosides and their analogs catalyzed by Pseudomonas cepacia lipase: Enzyme substrate recognition. Tetrahedron 2009, 65, 1063-1068. [CrossRef]

13. Yuan, L.; Wang, J.; Shen, W.-C. Lipidization of human interferon-alpha: A new approach toward improving the delivery of protein drugs. J. Controll. Release 2008, 129, 11-17. [CrossRef] [PubMed] 
14. Draper, J.M.; Xia, Z.; Smith, C.D. Cellular palmitoylation and trafficking of lipidated peptides. J. Lipid Res. 2007, 48, 1873-1884. [CrossRef] [PubMed]

15. Reetz, M.T. Biocatalysis in Organic Chemistry and Biotechnology: Past, Present, and Future. J. Am. Chem. Soc. 2013, 135, 12480-12496. [CrossRef] [PubMed]

16. Wallace, S.; Balskus, E.P. Opportunities for merging chemical and biological synthesis. Curr. Opin. Biotechnol. 2014, 30. [CrossRef] [PubMed]

17. Busto, E.; Gotor-Fernandez, V.; Gotor, V. Hydrolases: Catalytically promiscuous enzymes for non-conventional reactions in organic synthesis. Chem. Soc. Rev. 2010, 39, 4504-4523. [CrossRef] [PubMed]

18. Mateo, C.; Palomo, J.M.; Fernandez-Lorente, G.; Guisan, J.M.; Fernandez-Lafuente, R. Improvement of enzyme activity, stability and selectivity via immobilization techniques. Enzyme Microb. Technol. 2007, 40, 1451-1463. [CrossRef]

19. Adlercreutz, P. Immobilisation and application of lipases in organic media. Chem. Soc. Rev. 2013, 42, 6406-6436. [CrossRef] [PubMed]

20. Sheldon, R.A. Enzyme Immobilization: The Quest for Optimum Performance. Adv. Synth. Catal. 2007, 349, 1289-1307. [CrossRef]

21. Palomo, J.M.; Filice, M. New emerging bio-catalysts design in biotransformations. Biotechnol. Adv. 2015, 605-613. [CrossRef] [PubMed]

22. Romero, O.; Rivero, C.W.; Guisan, J.M.; Palomo, J.M. Novel enzyme-polymer conjugates for biotechnological applications. Peer J. 2013, 1. [CrossRef] [PubMed]

23. Payne, R.J.; Wong, C.-H. Advances in chemical ligation strategies for the synthesis of glycopeptides and glycoproteins. Chem. Commun. 2010, 46, 21-43. [CrossRef] [PubMed]

24. Gutarra, M.L.E.; Romero, O.; Abian, O.; Torres, F.A.G.; Freire, D.M.G.; Castro, A.M.; Guisan, J.M.; Palomo, J.M. Enzyme Surface Glycosylation in the Solid Phase: Improved Activity and Selectivity of Candida Antarctica Lipase B. Chem. Cat. Chem. 2011, 3, 1902-1910. [CrossRef]

25. Díaz-Rodríguez, A.; Davis, B.G. Chemical modification in the creation of novel biocatalysts. Opin. Chem. Biol. 2011, 15, 211-219. [CrossRef] [PubMed]

26. Filice, M.; Romero, O.; Guisan, J.M.; Palomo, J.M. Trans,trans-2,4-Hexadiene incorporation on enzymes for site-specific immobilization and fluorescent labeling. Org. Biomol.Chem. 2011, 9, 5535-5540. [CrossRef] [PubMed]

27. Romero, O.; Filice, M.; Rivas, B.D.L.; Carrasco-Lopez, C.; Klett, J.; Morreale, A.; Hermoso, J.A.; Guisan, J.M.; Abian, O.; Palomo, J.M. Semisynthetic peptide-lipase conjugates for improved biotransformations. Chem. Commun. 2012, 48, 9053-9055. [CrossRef] [PubMed]

28. Filice, M.; Guisan, J.M.; Terreni, M.; Palomo, J.M. Regioselective monodeprotection of peracetylated carbohydrates. Nat. Prot. 2012, 7, 1783-1796. [CrossRef] [PubMed]

29. Quintana, P.G.; Guillén, M.; Marciello, M.; Valero, F.; Palomo, J.M.; Baldessari, A. Immobilized Heterologous Rhizopus Oryzae Lipase as an Efficient Catalyst in the Acetylation of Cortexolone. Eur. J. Org. Chem. 2012, 2012, 4306-4312. [CrossRef]

30. Palomo, J.M.; Cabrera, Z. Enzymatic Desymmetrization of Prochiral Molecules. Curr. Org. Synth. 2012, 9, 791-805. [CrossRef]

31. Brabcová, J.; Blažek, J.; Janská, L.; Krečmerová, M.; Zarevúcka, M. Lipases as Tools in the Synthesis of Prodrugs from Racemic 9-(2, 3-Dihydroxypropyl) adenine. Molecules 2012, 17, 13813-13824. [CrossRef] [PubMed]

Sample Availability: Samples of the compounds (S)-9-(2,3-dihydroxypropyl)adenine (DHPA) and palmitoylated DHPA are available from the authors.

(C) 2016 by the authors; licensee MDPI, Basel, Switzerland. This article is an open access article distributed under the terms and conditions of the Creative Commons Attribution (CC-BY) license (http://creativecommons.org/licenses/by/4.0/). 